\title{
Особливості ензимної ланки антиоксидантного захисту в ранній період краніоскелетної травми, ускладненої крововтратою, у щурів із різною резистентністю до гіпоксії
}

\begin{abstract}
Мета роботи: встановити активність ензимної ланки антиоксидантного захисту в динаміці раннього періоду краніоскелетної травми, ускладненої крововтратою, у щурів з різною резистентністю до гіпоксії.

Матеріали і методи. Експерименти виконано на 148 нелінійних білих щурах-самцях масою 180-200 г, які знаходилися на стандартному раціоні віварію. Попередньо у щурів визначили індивідуальну стійкість до гіпоксії й виділили дві групи: високо- і низькостійких (BC, НС). У тварин моделювали краніоскелетну травму та поєднували ії з гострою крововтратою. Через 1 , 3 і 7 діб у печінці різностійких до гіпоксії тварин визначали супероксиддисмутазну (СОД-) та каталазну активність.

Результати досліджень та їх обговорення. Характерною особливістю ВС тварин порівняно з НС тваринами контрольної групи був вищий рівень СОД- та каталазної активності печінки. У відповідь на краніоскелетну травму активність досліджуваних ензимів у печінці НС і ВС тварин знижувалася з максимумом через 3 доби й залишалася на такому ж рівні до 7 доби. Проте у ВС тварин після нанесення краніоскелетної травми відмічали менший ступінь зниження досліджуваного показника. За умов моделювання додаткової крововтрати порушення ензимної ланки антиоксидантного захисту в печінці були більшими й зростали з 1 до 7 діб. Однак у ВС тварин порушення СОД-активності у всі терміни посттравматичного періоду було меншим. Каталазна активність у відповідь на модельовані травми у ВС тварин через 3 і 7 діб посттравматичного періоду була меншою як за умов моделювання лише краніоскелетної травми, так і її поєднання з гострою крововтратою. Отримані результати націлюють на необхідність врахування індивідуальної стійкості до гіпоксії у розробці стратегій діагностики та корекції травматичної хвороби за умов політравми та диференційованого застосування речовин з антиоксидантними властивостями, що вимагає свого подальшого поглибленого дослідження.
\end{abstract}

Ключові слова: краніоскелетна травма; крововтрата; стійкість до гіпоксії; супероксиддисмутази; каталаза.

Постановка проблеми і аналіз останніх досліджень та публікацій. Порушення ензимної ланки антиоксидантного захисту відіграє ключову роль в патогенезі політравми. Внаслідок травматичного шоку, синдрому гіперметаболізму, порушень мікроциркуляції, активації лейкоцитів, які мігрують до зони пошкодження, у тканинах й органах травмованого організму виникають передумови утворення активних форм оксигену (АФО) [4]. Їхнім прямим наслідком $є$ вільнорадикальне окиснення ліпідів і білків клітинних мембран з їхньою деградацією й формуванням синдрому поліорганної дисфункції [9].

За умов травми незначної сили одночасно активується система антиоксидантного захисту, яка здатна компенсувати дефіцит антиоксидантів i підтримувати антиоксидантно-прооксидантний баланс. При травмі значної сили інтенсивність процесів пероксидного окиснення виходить 3-під контролю і вважається пусковим чинником розвитку системної відповіді організму на запалення 3 вторинним ураженням тканин, віддалених від місця безпосереднього пошкодження [3].

Як відомо, інтенсивність процесів ліпідної пероксидації залежить від стійкості організму до гіпоксії [6]. Прояв цієї конституційної властивос- ті організму практично не вивчений за умов травматичної хвороби, яка є наслідком тяжкої поєднаної травми.

У наших попередніх дослідженнях показано, що після моделювання краніоскелетної травми, ускладненої гострою крововтратою, в ранній період травматичної хвороби у високостійких до гіпоксії тварин реакція на травму супроводжується меншою активізацією процесів ліпідної пероксидації, ніж у низькостійких тварин [8]. Однак стан ензимної антиоксидантної системи, зокрема супероксиддисмутазна (СОД-активність) та каталазна активність, які забезпечують основний рубіж захисту від АФО, за цих умов практично не вивчена.

Мета роботи: 3'ясувати активність ензимної ланки антиоксидантного захисту в динаміці раннього періоду краніоскелетної травми, ускладненої крововтратою, у щурів з різною резистентністю до гіпоксії.

Матеріали і методи. Експерименти виконано на 148 нелінійних білих щурах-самцях масою 180-200 г, які знаходилися на стандартному раціоні віварію. Попередньо за методикою, описаною в роботі [7], у щурів визначили індивідуальну стійкості до гіпоксії й виділили дві групи: високо- 
i низькостійких (BC і НС). Через 14 днів ВС і НС тварини розділили на 3 групи: контрольну (по 6 інтактних щурів) та дві дослідних (по 68 щурів). В умовах тіопентал-натрієвого наркозу $\left(40 \mathrm{M} \Gamma^{\cdot} \cdot \Gamma^{-1}\right)$ у першій дослідній групі моделювали краніоскелетну травму шляхом послідовного нанесення дозованого удару по черепу з досягненням закритої черепно-мозкової травми середнього ступеня тяжкості та дозованого удару по стегну ударним пристроєм 3 клиноподібною насадкою 3 досягненням закритого перелому стегна [2]. У другій дослідній групі додатково моделювали гостру крововтрату в об’ємі 20-22 \% об’єму циркулюючої крові [12].

Тварин виводили 3 експерименту в умовах наркозу через 1, 3 і 7 діб посттравматичного періоду. Для дослідження брали печінку, в гомогенаті якої визначали СОД-активність (КФ 1.1.15.1.) [10] і каталазну активність (КФ 1.11.1.6) [5]. Розраховували абсолютні величини досліджуваних показників, а також відношення індивідуальних величин до середньої величини контрольної групи, що пов'язано з різним рівнем активності досліджуваних ензимів у ВС і НС щурів контрольної групи. Статистичний аналіз отриманих результатів проводили з використанням критерію Манна-Уїтні в програмному пакеті STATISTICA 10.0 ("StatSoft, Inc.”, США).

Результати досліджень та їх обговорення. Дослідження показали, що в контрольній групі відмічали більшу СОД-активність у печінці ВС тварин порівняно з НС тваринами (на 24,6 \%, $\mathrm{p}<0,05)$ (табл. 1). В умовах краніоскелетної травми у НС і ВС тварин СОД-активність в печінці істотно знижувалася порівняно з контролем впродовж усього терміну спостереження. Показник досягав мінімальної величини до 3 доби й був меншим порівняно з контролем, відповідно, на 46,1 та 32,1 \% $(\mathrm{p}<0,05)$. До 7 доби у НС тварин показник істотно зростав порівняно з попереднім терміном спостереження (на 25,7 \%, p<0,05), проте у групі ВС тварин залишався на такому ж рівні (p>0,05). По-

Таблиця 1. Динаміка супероксиддисмутазної активності (ум.од. кг-1) у відповідь на краніоскелетну травму, ускладнену крововтратою, у тварин із різною стійкістю до гіпоксії (Me (LQ; UQ)) - медіана (нижній і верхній квартилі)

\begin{tabular}{|c|c|c|c|c|}
\hline \multirow{2}{*}{$\begin{array}{l}\text { Стійкість до } \\
\text { гіпоксії }\end{array}$} & \multirow{2}{*}{ Контроль } & \multicolumn{3}{|c|}{ Термін посттравматичного періоду } \\
\hline & & 1 доба & 3 доба & 7 доба \\
\hline \multicolumn{5}{|c|}{ Краніоскелетна травма } \\
\hline Низькостійкі & $\begin{array}{c}0,65 \\
(0,59 ; 0,71) \\
(n=6)\end{array}$ & $\begin{array}{c}0,48^{*} \\
(0,47 ; 0,53) \\
(n=7)\end{array}$ & 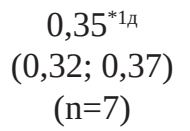 & $\begin{array}{c}0,44^{\text {*ад }} \\
(0,39 ; 0,48) \\
(n=7)\end{array}$ \\
\hline Високостійкі & $\begin{array}{c}0,81^{\#} \\
(0,73 ; 0,83) \\
(n=6)\end{array}$ & $\begin{array}{c}0,68^{* \#} \\
(0,64 ; 0,72) \\
(n=8)\end{array}$ & $\begin{array}{c}0,55^{* \# 1 д ~} \\
(0,49 ; 0,58) \\
(n=10)\end{array}$ & $\begin{array}{c}0,64^{\# * 1 д} \\
(0,58 ; 0,64) \\
(n=10)\end{array}$ \\
\hline \multicolumn{5}{|c|}{ Краніоскелетна травма + крововтрата } \\
\hline Низькостійкі & $\begin{array}{c}0,65 \\
(0,59 ; 0,71) \\
(n=6)\end{array}$ & $\begin{array}{c}0,40^{*} \\
(0,33 ; 0,42) \\
(n=6)\end{array}$ & $\begin{array}{c}0,32^{*} \\
(0,29 ; 0,34) \\
(n=6)\end{array}$ & $\begin{array}{c}0,22^{* 1 д, з д ~} \\
(0,21 ; 0,26) \\
(n=5)\end{array}$ \\
\hline Високостійкі & $\begin{array}{c}0,81^{\#} \\
(0,73 ; 0,83) \\
(n=6)\end{array}$ & $\begin{array}{c}0,62^{* \#} \\
(0,56 ; 0,63) \\
(n=8)\end{array}$ & $\begin{array}{c}0,57^{* \#} \\
(0,48 ; 0,60) \\
(n=9)\end{array}$ & $\begin{array}{c}0,50^{\text {*1д }} \\
(0,46 ; 0,54) \\
(n=8)\end{array}$ \\
\hline \multicolumn{2}{|c|}{$\mathrm{p}_{1}$} & $<0,05$ & $>0,05$ & $<0,05$ \\
\hline \multicolumn{2}{|c|}{$\mathrm{p}_{2}$} & $>0,05$ & $>0,05$ & $>0,05$ \\
\hline
\end{tabular}

Примітки. Тут і в інших таблицях 2-4:

1) * - відмінності стосовно контрольної групи статистично вірогідні $(\mathrm{p}<0,05)$;

2) \# - відмінностей між групами ВС і НС тварин статистично вірогідні (p<0,05);

3) 1д,зд - відмінності стосовно 1 і 3 діб спостереження статистично вірогідні $(\mathrm{p}<0,05)$;

4) $\mathrm{p}_{1}$ - вірогідність відмінностей у групах НС тварин із наявною та відсутньою додатковою крововтратою;

5) $\mathrm{p}_{2}$ - вірогідність відмінностей у групах ВС тварин із наявною та відсутньою додатковою крововтратою. 
рівняння між собою груп ВС і НС тварин із краніоскелетною травмою показало, що у всі терміни спостереження активність СОД в печінці була статистично вірогідно більшою у ВС тварин, порівняно з НС тваринами (відповідно, на 41,7, 57,1 та 45,4 \%, $\mathrm{p}<0,05)$.

За умов додаткової крововтрати порушення активності СОД у печінці були більшими. Показник в обох групах до 7 доби знижувався й у групі НС тварин у цей термін був меншим, порівняно з контролем на 66,2 \%, у групі ВС тварин - на $38,3$ \% ( $<0,05)$. Порівняння між собою дослідних груп тварин із краніоскелетною травмою, ускладненою крововтратою, показало, що у групі ВС тварин показник теж в усі терміни спостереження виявився статистично вірогідно більшим, ніж у НС тварин (через 1 добу - на 55,0 \%, через 3 доби - на 47,1 \%, через 7 діб - у 2,27 раза, p<0,05).

Аналіз впливу додаткової крововтрати на динаміку СОД-активності печінки у НС тварин на тлі краніоскелетної травми показав, що за цих умов показник через 1 і 7 діб посттравматичного періоду був статистично вірогідно меншим, порівняно з НС тваринами без крововтрати (відпо-

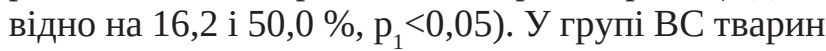
додаткова крововтрата зумовила статистично вірогідне зменшення цього показника тільки через 7 діб есперименту (на 21,9 \%, $\mathrm{p}_{2}<0,05$ ).
Враховуючи, що у контрольній групі ВС i НС до гіпоксії тварин СОД-активність була різною, ми визначили відношення індивідуальних величин цього показника до середньої величини контрольної групи (табл. 2). Аналіз отриманих результатів показав, що за умов моделювання лише краніоскелетної травми величина досліджуваного показника у всі терміни спостереження у групі ВС тварин була істотно більшою, ніж у групі НС тварин: через 1 добу - на 18,9 \%, через 3 доби - на 31,5 \%, через 7 діб - на 22,0 \% (p<0,05). За умов додаткового моделювання гострої крововтрати результат виявився аналогічним. У ВС тварин величина досліджуваного показника була більшою, порівняно з НС тваринами, відповідно, на 30,6, 64,4 та 91,2 \% $(\mathrm{p}<0,05)$.

Аналіз каталазної активності у групах піддослідних тварин показав (табл. 3), що у контрольній групі ВС тварин показник був на 12,3 \% більшим, ніж у групі НС тварин $(\mathrm{p}<0,05)$. За умов краніоскелетної травми у НС і ВС тварин показник порівняно $з$ контролем знижувався, досягаючи мінімальної величини до 3 доби експерименту: відповідно на 35,6 та $20,2 \%(p<0,05)$ й залишався на такому ж рівні до 7 доби. Порівняння дослідних груп між собою показало, що у групі ВС тварин у всі терміни посттравматичного періоду активність каталази печінки була статистично вірогідно більшою: через

Таблиця 2. Динаміка середнього відношення індивідуальних величин СоД-активності до середньої величини контрольної групи у відповідь на краніоскелетну травму, ускладнену крововтратою, у тварин 3 різною стійкістю до гіпоксії (Me (LQ; UQ)) - медіана (нижній і верхній квартилі)

\begin{tabular}{|c|c|c|c|}
\hline \multirow{2}{*}{ Стійкість до гіпоксії } & \multicolumn{3}{|c|}{ Термін посттравматичного періоду } \\
\hline & 1 доба & 3 доба & 7 доба \\
\hline \multicolumn{4}{|c|}{ Краніоскелетна травма } \\
\hline Низькостійкі & $\begin{array}{c}0,74 \\
(0,72 ; 0,82) \\
(n=7)\end{array}$ & $\begin{array}{c}0,54 \\
(0,49 ; 0,56) \\
(n=7)\end{array}$ & $\begin{array}{c}0,68 \\
(0,60 ; 0,74) \\
(n=7)\end{array}$ \\
\hline Високостійкі & $\begin{array}{c}0,88^{\#} \\
(0,83 ; 0,94) \\
(n=8)\end{array}$ & $\begin{array}{c}0,71^{\#} \\
(0,63 ; 0,75) \\
(n=10)\end{array}$ & $\begin{array}{c}0,83^{\#} \\
(0,75 ; 0,83) \\
(n=10)\end{array}$ \\
\hline \multicolumn{4}{|c|}{ Краніоскелетна травма + крововтрата } \\
\hline Низькостійкі & $\begin{array}{c}0,62 \\
(0,50 ; 0,65) \\
(n=7)\end{array}$ & $\begin{array}{c}0,49 \\
(0,45 ; 0,52) \\
(n=7)\end{array}$ & $\begin{array}{c}0,34 \\
(0,32 ; 0,40) \\
(n=7)\end{array}$ \\
\hline Високостійкі & $\begin{array}{c}0,81^{\#} \\
(0,73 ; 0,82) \\
(n=8)\end{array}$ & $\begin{array}{c}0,74^{\#} \\
(0,62 ; 0,78) \\
(n=10)\end{array}$ & $\begin{array}{c}0,65^{\#} \\
(0,60 ; 0,69) \\
(n=10)\end{array}$ \\
\hline
\end{tabular}


Таблиця 3. Динамка каталазної активності (мккат·кг-1) у відповідь на краніоскелетну травму, ускладнену крововтратою, у тварин з різною стійкістю до гіпоксії (Me (LQ; UQ)) - медіана (нижній і верхній квартилі)

\begin{tabular}{|c|c|c|c|c|}
\hline \multirow{2}{*}{$\begin{array}{l}\text { Стійкість до } \\
\text { гіпоксії }\end{array}$} & \multirow[t]{2}{*}{ Контроль } & \multicolumn{3}{|c|}{ Термін посттравматичного періоду } \\
\hline & & 1 доба & 3 доба & 7 доба \\
\hline \multicolumn{5}{|c|}{ Краніоскелетна травма } \\
\hline Низькостійкі & $\begin{array}{c}1,15 \\
(1,05 ; 1,18) \\
(\mathrm{n}=6)\end{array}$ & $\begin{array}{c}0,98 \\
(0,91 ; 1,05) \\
(\mathrm{n}=7)\end{array}$ & $\begin{array}{c}0,74^{* 1 д} \\
(0,69 ; 0,77) \\
(\mathrm{n}=7)\end{array}$ & $\begin{array}{c}0,77^{* 1_{\text {д }}} \\
(0,71 ; 0,90) \\
(\mathrm{n}=7)\end{array}$ \\
\hline Високостійкі & $\begin{array}{c}1,29^{\#} \\
(1,23 ; 1,34) \\
(\mathrm{n}=6)\end{array}$ & $\begin{array}{c}1,16^{* \#} \\
(1,11 ; 1,17) \\
(n=8)\end{array}$ & $\begin{array}{c}1,03^{* * 11_{д}} \\
(0,95 ; 1,07) \\
(\mathrm{n}=10)\end{array}$ & $\begin{array}{c}1,13^{* \#} \\
(1,02 ; 1,16) \\
(n=10)\end{array}$ \\
\hline \multicolumn{5}{|c|}{ Краніоскелетна травма + крововтрата } \\
\hline Низькостійкі & $\begin{array}{c}1,15 \\
(1,05 ; 1,18) \\
(n=6)\end{array}$ & $\begin{array}{c}0,92^{*} \\
(0,85 ; 1,01) \\
(\mathrm{n}=6)\end{array}$ & $\begin{array}{c}0,63^{* 1 д} \\
(0,58 ; 0,67) \\
(\mathrm{n}=6)\end{array}$ & $\begin{array}{c}0,51^{* 1,3,3 \AA} \\
(0,48 ; 0,54) \\
(n=5)\end{array}$ \\
\hline Високостійкі & $\begin{array}{c}1,29^{\#} \\
(1,23 ; 1,34) \\
(\mathrm{n}=6)\end{array}$ & $\begin{array}{c}1,06^{*} \\
(1,01 ; 1,09) \\
(n=8)\end{array}$ & $\begin{array}{c}0,96^{* \#} \\
(0,82 ; 1,02) \\
(\mathrm{n}=9)\end{array}$ & $\begin{array}{c}0,87^{* \# 1_{д}} \\
(0,77 ; 0,98) \\
(n=8)\end{array}$ \\
\hline \multicolumn{2}{|c|}{$\mathrm{p}_{1}$} & $>0,05$ & $<0,05$ & $<0,05$ \\
\hline \multicolumn{2}{|c|}{$\mathrm{p}_{2}$} & $>0,05$ & $>0,05$ & $<0,05$ \\
\hline
\end{tabular}

1 добу - на 18,4 \%, через 3 доби - на 39,2 \%, через 7 діб - на 46,8 \% ( $<0,05)$.

Додаткова крововтрата зумовлювала ще більше зниження активності каталази. Показник в обох дослідних групах порівняно з контролем поступово знижувався й досягав мінімального рівня через 7 діб. У групі НС тварин показник стосовно контролю знижувався на 55,6 \%, у групі ВС тварин - на 32,6 \% ( $<0,05)$. Порівняння дослідних груп показало, що у ВС тварин показник через 3 і 7 діб був статистично вірогідно більшим, ніж у групі НС тварин: відповідно на 52,4 і 70,6 \% $(\mathrm{p}<0,05)$.

Аналіз впливу додаткової крововтрати на динаміку каталазної активності у НС тварин на тлі краніоскелетної травми показав, що додаткова крововтрата сприяла статистично вірогідному зниженню каталазної активності через 3 і 7 діб посттравматичного періоду (відповідно, на 14,9 і 33,8 \%, p $\left._{1}<0,05\right)$. У групі ВС тварин додаткова крововтрата зумовила статистично вірогідне зменшення цього показника тільки через 7 діб експерименту (відповідно, на 23,0%, $\mathrm{p}_{2}<0,05$ ).

Дослідження динаміки середнього відношення індивідуальних величин каталазної активності до середньої величини контрольної групи у відповідь на краніоскелетну травму показало, що у ВС тварин показник через 3 доби був істотно більшим, ніж у групі НС тварин (на 25,0 \%, p<0,05). Після моделювання краніоскелетної травми, ускладненої гострою крововтратою, досліджуваний показник у групі ВС виявився статистично вірогідно більшим через 3 і 7 діб порівняно з НС тваринами (відповідно, на 45,1 та 94,1%, р<0,05 (табл. 4).

Отримані результати свідчать про те, що характерною особливістю ВС тварин, порівняно 3 НС тваринами контрольної групи, є вищий рівень показників ензимної ланки антиоксидантного захисту, зокрема СОД- та каталазної активності. Можна припустити, що така особливість є конституційною й спрямована на компенсацію більшої інтенсивності процесів ліпідної пероксидації, що було виявлено у попередніх дослідженнях [8].

У відповідь на краніоскелетну травму активність досліджуваних ензимів у печінці НС і ВС тварин знижувалася з максимумом через 3 доби й залишалася на такому ж рівні до 7 доби. Зниження СОД- та каталазної активності є закономірною реакцією на краніоскелетну травму і свідчить, з одного боку, про надмірне утворення АФО, з іншого - про інтенсивне використання цих ензимів для їх нейтралізації [1]. 
Таблиця 4. Динаміка середнього відношення індивідуальних величин каталазної активності до середньої величини контрольної групи у відповідь на краніоскелетну травму, ускладнену крововтратою, у тварин з різною стійкістю до гіпоксії (Me (LQ; UQ)) - медіана (нижній і верхній квартилі)

\begin{tabular}{|c|c|c|c|}
\hline \multirow{2}{*}{ Стійкість до гіпоксії } & \multicolumn{3}{|c|}{ Термін посттравматичного періоду } \\
\hline & 1 доба & 3 доба & 7 доба \\
\hline \multicolumn{4}{|c|}{ Краніоскелетна травма } \\
\hline Низькостійкі & $\begin{array}{c}0,85 \\
(0,79 ; 0,91) \\
(n=7)\end{array}$ & $\begin{array}{c}0,64 \\
(0,60 ; 0,67) \\
(n=7)\end{array}$ & $\begin{array}{c}0,68 \\
(0,62 ; 0,79) \\
(n=7)\end{array}$ \\
\hline Високостійкі & $\begin{array}{c}0,90 \\
(0,86 ; 0,90) \\
(n=8)\end{array}$ & $\begin{array}{c}0,80^{\#} \\
(0,73 ; 0,83) \\
(n=10)\end{array}$ & $\begin{array}{c}0,86 \\
(0,78 ; 0,89) \\
(n=10)\end{array}$ \\
\hline \multicolumn{4}{|c|}{ Краніоскелетна травма + крововтрата } \\
\hline Низькостійкі & $\begin{array}{c}0,80 \\
(0,74 ; 0,87) \\
(n=6)\end{array}$ & $\begin{array}{c}0,51 \\
(0,34 ; 0,57) \\
(n=6)\end{array}$ & $\begin{array}{c}0,34 \\
(0,32 ; 0,40) \\
(n=5)\end{array}$ \\
\hline Високостійкі & $\begin{array}{c}0,82 \\
(0,78 ; 0,84) \\
(n=8)\end{array}$ & $\begin{array}{c}0,74^{\#} \\
(0,64 ; 0,79) \\
(n=9)\end{array}$ & $\begin{array}{c}0,66^{\#} \\
(0,58 ; 0,74) \\
(n=8)\end{array}$ \\
\hline
\end{tabular}

Проте, як показали наші дослідження, у ВС до гіпоксії тварин після нанесення краніоскелетної травми абсолютна СОД-активність у всі терміни експерименту була більшою, ніж у НС тварин. Так само у групі ВС тварин меншим виявився i ступінь зниження досліджуваного показника. Цілком ймовірно, що у ВС тварин за цих умов меншими $є$ передумови утворення АФО, які, як відомо, $є$ пусковим механізмом системних порушень, в тому числі системної відповіді організму на запалення та поліорганної дисфункції [3].

За умов моделювання додаткової крововтрати порушення ензимної ланки антиоксидантного захисту в печінці були більшими, що пов'язано 3 компенсаторним перерозподілом кровотоку з обмеженням кровопостачання органів шлунковокишкового тракту та поглибленням гіпоксії [11]. Однак знову ж у ВС тварин порушення СОДактивності у всі терміни посттравматичного періоду було меншим, що вказує на більшу потужність антиоксидантного захисту у цій групі тварин. Саме цим, ймовірно, можна пояснити менший ступінь зростання інтенсивності ліпопероксидації у печінці за умов краніоскелетної травми, ускладненої крововтратою, що встановлено нашими попередніми дослідженнями [8].

Що стосується динаміки каталазної активності у відповідь на модельовані травми, то закономірність була аналогічною: ступінь зниження досліджуваного показника у ВС тварин через 3 і 7 діб посттравматичного періоду як за умов моделювання лише краніоскелетної травми, так і її поєднання з гострою крововтратою був меншим.

Важливо зазначити, що моделювання додаткової крововтрати призводило до більшого зниження СОД- та каталазної активності у групах НС до гіпоксії тварин. Водночас у ВС тварин крововтрата істотно не вплинула на СОД-активність та сприяла зниженню каталазної активності тільки через 7 діб експерименту. Ці результати підтверджують припущення про те, що у ВС до гіпоксії тварини АФО як провідний чинник патогенезу краніоскелетної трамви, ускладненої крововтратою, відіграє меншу роль, порівняно з НС до гіпоксії тварин.

Отримані результати націлюють на необхідність врахування індивідуальної стійкості до гіпоксії у розробці стратегій діагностики та корекції травматичної хвороби за умов політравми та диференційованого застосування речовин $з$ антиоксидантними властивостями, що вимагає подальшого поглибленого дослідження.

Висновки. 1. ВС до гіпоксії тварини характеризуються вищою СОД- та каталазою активністю, порівняно з НС до гіпоксії тваринами.

2. У відповідь на краніоскелетну травму настає виснаження ензимної ланки антиоксидантного захисту печінки з максимумом через 3 доби, однак ступінь зниження СОД- та каталазної активності є нижчим у ВС до гіпоксії тварин. 
3. Додаткове моделювання гострої крововтрати за умов краніоскелетної травми супроводжується більшим виснаженням ензимної ланки антиоксидантного захисту печінки, яке більш виражено у НС до гіпоксії тварин.

\section{СПИСОК ЛІТЕРАТУРИ}

1. Борис Р. М. Динаміка показників ферментативної ланки антиоксидантного захисту в період ранніх та пізніх проявів травматичної хвороби в умовах експериментальної краніоскелетної травми та її корекції клітинною терапією / Р. М. Борис, А. М. Гольцев, А. І. Гоженко // Архив клинической и экспериментальной медицины. - 2013. - Т. 22, № 1. - С. 2328.

2. Борис Р. М. Динаміка показників пероксидного окиснення ліпідів у період ранніх і пізніх проявів травматичної хвороби за умов експериментальної краніоскелетної травми та іїі корекції клітинною терапією / Р. М. Борис, А. І. Гоженко, А. А. Гудима // Клінічна та експериментальна патологія. 2013. - T. XII, № 2 (44). - C. 31-34.

3. Козак Д. В. Вплив карбацетаму на антиоксидантний-прооксидантний баланс тканини серця, легень і печінки в динаміці політравми / Д. В. Козак // Шпитальна хірургія. - 2014. № 1 (65). - С. 40-42.

4. Козак Д. В. Особливості показників пероксидного окислення ліпідів в динаміці раннього і пізнього періодів політравми / Д. В. Козак // Актуальные проблемы транспортной медицины. - 2012. - № 3 (29). - С. 103-106.

5. Метод определения активности каталазы / М. А. Королюк, Л. И. Иванова, И. Г. Майорова, В. Е. Токарев // Лабораторное дело. - 1988. - № 1. - С. 16-19.

6. Ординський Ю. М. Зміни пероксидного окиснення ліпідів та антиоксидантного захисту в щурів різної статі, високо- і низькостійких до гострої гіпоксичної гіпоксії при іммобілізаційному стрес / Ю. М. Ординський, О. В. Денефіль // Вісник наукових досліджень. - 2019. - № 2. - С. 101-104.

\section{REFERENCES}

1. Borys, R.M., Goltsev, A.M., \& Gozhenko, A.I. (2013). Dynamika pokaznykiv fermentatyvnoi lanky antyoksydantnoho zakhystu $\mathrm{v}$ period rannikh ta piznikh proiaviv travmatychnoi khvoroby v umovakh eksperymentalnoi kranio-skeletnoi travmy ta yii korektsii klitynnoiu terapiieiu [The dynamics of fermentative branch of antioxidant protection indices during early and late manifestations of traumatic disease under the conditions of experimental cranio-skeletal injury and its correction by cell therapy]. Arkhiv klinicheskoy i eksperymentalnoy medytsyny - Archives of Clinical and Experimental Medicine, 22 (1), 23-28 [in Ukrainian]. 2. Borys, R.M., Gozhenko, A.I., \& Gudyma, A.A. (2013). Dynamika pokaznykiv peroksydnoho okysnennia lipidiv u period rannikh i piznikh proiaviv travmatychnoi khvoroby za umov eksperymentalnoi kranioskeletnoi travmy ta yii korektsii klitynnoiu terapiieiu [The dynamics of lipid peroxidation indices during early and late manifestations of traumatic disease under conditions of experimental cranioskeletal injury and its correction by cell therapy]. Klinichna ta eksperymentalnapatolohiia - Clinical and Experimental Pathology, KHII, 2 (44), 31-34 [in Ukrainian].

3. Kozak, D.V. (2014). Vplyv karbatsetamu na antyoksydant-
Перспективи подальших досліджень. У перспективі доцільно вивчити ефективність застосування речовин $з$ антиоксидантними властивостями у ВС і НС до гіпоксії тварин за умов краніоскелетної травми, ускладненої крововтратою.

7. Сатурська Г. С. Особливості метаболізму сполучної тканини при експериментальному дифузному ішемічно-некротичному кардіосклерозі у щурів із різною стійкістю до гіпокciї / Г. С. Сатурська, Ю. І. Бондаренко // Вісник ВНМУ. 2014. - T. 18, № 2. - С. 425-429.

8. Сікіринська Д. О. Особливості активації процесів ліпідної пероксидації в ранній період краніоскелетної травми, ускладненої крововтратою, у щурів з різною резистентністю до гіпоксії / Д. О. Сікіринська, А. А. Гудима, К. А. Походун // Медична та клінічна хімія. - 2020. - Т. 22, № 3. - С. 107-113. 9. Цимбалюк Г. Ю. Динаміка змін в антиоксидантно-прооксидантній системі в тканинах нирок при поєднаній травмі органів черевної порожнини на фоні гіповолемічного шоку та синдромі ішемії-реперфузії / Г. Ю. Цимбалюк // Шпитальна хірургія. Журнал імені Л. Я. Ковальчука. - 2018. - Вип. 3 (38). - С. 63-69.

10. Чевари С. Роль супероксиддисмутазы в окислительных процессах клетки и метод определения ее в биологических материалах / С. Чевари, И. Чаба, Й. Сокей // Лаболаторное дело. 1985. - № 11. - C. 678-681.

11. Antioxidant-prooxidant balance in abdominal injury, hypovolemic shock and reperfusion syndrom of the limbs in experiment / V. O. Krylyuk, V. K. Grodetskyi, I. V. Kuzminsky, G. Yu. Tsymbalyk // The Unity of Science. - 2019. - No. 1. - P. 149-153.

12. Influence of two-hour tourniquets ischemia of limb and acute blood loss on systemic disorders of the body in the reperfusion period (experimental study) / I. I. Horban, A. A. Hudyma, R. V. Maksymiv, I. V. Antonyshyn // Wiad. Lek. - 2020. - Vol. LXXIII, Iss. 7. - P. 1330-1333. nyi-prooksydantnyi balans tkanyny sertsia, lehen i pechinky v dynamitsi politravmy [Effect of carbacetam on antioxidant and prooxidant balance of heart lungs and liver tissues in polytrauma dynamic]. Shpytalna khirurhiia - Hospital Surgary, 1 (65), 40-42. DOI: https://doi.org/10.11603/1681-2778.2014.1.4362 [in Ukrainian].

4. Kozak, D.V. (2012). Osoblyvosti pokaznykiv peroksydnoho okyslennia lipidiv v dynamitsi rannoho i piznoho periodiv politravmy [Dynamics of lipids peroxidation datas in the early and late periods of polytrauma]. Aktualnye problemy transportnoy medytsyny - Actual Problems of Transport Medicine, 3 (29), 103106 [in Ukrainian].

5. Korolyuk, M.A., Ivanova, L.I., Mayorova, I.G., \& Tokarev, V. Ye. (1988). Metod opredeleniya aktivnosti katalazy [Method for determining the activity of catalase]. Labolatornoye delo - Laboratory Business, 1, 16-19 [in Russian].

6. Ordynskyi, I.M., \& Denefil, O.V. (2019). Zminy peroksydnoho okysnennia lipidiv ta antyoksydantnoho zakhystu v shchuriv riznoi stati, vysoko- i nyzkostiikykh do hostroi hipoksychnoi hipoksii pry immobilizatsiinomu stresi [Changes of lipid pero- 
xidation and antioxidant defense of high and low-resistance to acute hypoxic hypoxia in rats of different sex in immobilizational stress]. Visnyk naukovykh doslidzhen - Bulletin of Scientific Research, 2, 101-104. DOI: https://doi.org/10.11603/24158798.2019.2.10270 [in Ukrainian].

7. Saturska, H.S., \& Bondarenko, Yu.I. (2014). Osoblyvosti metabolizmu spoluchnoi tkanyny pry eksperymentalnomu dyfuznomu ishemichno-nekrotychnomu kardiosklerozi u shchuriv iz riznoiu stiikistiu do hipoksii [Features of the connective tissue metabolism in experimental diffuse ischemic necrotic cardiosclerosis in rats w ith different resistance to hypoxia]. Visnyk VNMU - Bulletin VNMU, 18 (2), 425-429 [in Ukrainian].

8. Sikirynska, D.O., Hudyma, A.A., \& Pokhodun, K.A. (2020). Osoblyvosti aktyvatsii protsesiv lipidnoi peroksydatsii v rannii period kranioskeletnoi travmy, uskladnenoi krovovtratoiu, u shchuriv z riznoiu rezystentnistiu do hipoksii [Peculiarities of activation of lipid peroxidation processes in the early period of cranioskeletal injury complicated by blood loss in rats with different resistance to hypoxia]. Medychna ta klinichna khimiia Medical and Clinical Chemistry, 3, 107-113. DOI: https://doi. org/10.11603/mcch.2410-681X.2020.v.i3.11547 [in Ukrainian].

9. Tsymbaliuk, G.Yu. (2018). Dynamika zmin v antyoksydantno-prooksydantnii systemi $\mathrm{v}$ tkanynakh nyrok pry poiednanii travmi orhaniv cherevnoi porozhnyny na foni hipovolemichnoho shoku ta syndromi ishemii-reperfuzii [Dynamics of changes in antioxidant-prooxidant system in kidney tissues after trauma of abbdominal cavity with hypovolemic shock and ischemia-reperfusion syndrome]. Shpytalna khirurhiia. Zhurnal imeni L.Ya. Kovalchuka - Hospital Surgery. Journal Named by L.Ya. Kovalchuk, 3, 63-69. DOI: https://doi.org/10.11603/2414-4533.2018.3.8898 [in Ukrainian].

10. Chevari, S., Chaba, I., \& Sokey, Y. (1985). Rol superoksiddismutazy v okislitelnykh protsessakh kletki i metod opredeleniya yeye $\mathrm{v}$ biologicheskikh materialakh [The role of superoxide dismutase in the oxidative processes of the cell and the method for its determination in biological materials]. Labolatornoye delo - Laboratory Business, 11, 678-681 [in Russian].

11. Krylyuk, V.O., Grodetskyi, V.K., Kuzminsky, I.V., \& Tsymbalyk, G.Yu. (2019). Antioxidant-prooxidant balance in abdominal injury, hypovolemic shock and reperfusion syndrom of the limbs in experiment. The Unity of Science, 1, 149-153.

12. Horban, I.I., Hudyma, A.A., Maksymiv, R.V., \& Antonyshyn, I.V. (2020). Influence of two-hour tourniquets ischemia of limb and acute blood loss on systemic disorders of the body in the reperfusion period (experimental study). Wiad. Lek., LXXIII, 7, 1330-1333.

\title{
PECULIARITIES OF THE ENZYME LINK OF ANTIOXIDANT PROTECTION IN THE EARLY PERIOD OF CRANIOSKELETAL INJURY COMPLICATED BY BLOOD LOSS IN RATS WITH DIFFERENT HYPOXIA RESISTANCE
}

\begin{abstract}
The aim of the work: to elucidate the activity of the enezymic link of the antioxidant defense in the dynamics of the early period of cranioskeletal injury complicated by blood loss in rats with different resistance to hypoxia.

Materials and Methods. The experiments were performed on 148 nonlinear white male rats weighing 180-200 g, which were fed a standard vivarium diet. The rats were preliminarily determined to have individual resistance to hypoxia and two groups were identified: high- and low-resistant (HR, LR). Cranioskeletal trauma was modeled in animals and combined with acute blood loss. After 1, 3 and 7 days, superoxide dismutase (SOD-) and catalase activity was determined in the liver of animals that were not resistant to hypoxia. Results and its Discussion. High level of SOD- and catalase activity of the liver is a characteristic feature of HR animals in comparison with LR animals of the control group. In response to cranioskeletal trauma, the activity of the studied enzymes in the liver of HR and LR of animals decreased with a maximum after 3 days and remained at the same level for up to 7 days. However, in the HR of animals after cranioskeletal injury, a lesser degree of decrease in the studied parameter was noted. Under the conditions of simulating additional blood loss, violations of the enzyme link of antioxidant defense in the liver were large and increased from 1 to 7 days. However, in the HR of animals, the violation of SOD activity in all periods of the post-traumatic period was less. Catalase activity in response to simulated traumas in the HR of animals after 3 and 7 days of the post-traumatic period was lower both under conditions of simulating only cranioskeletal trauma and its combination with acute blood loss. The results obtained aim at the need to take into account individual resistance to hypoxia in the development of strategies for the diagnosis and correction of traumatic disease in conditions of polytrauma and the differentiated use of substances with antioxidant properties, and requires further in-depth research.
\end{abstract}

Key words: cranioskeletal injury; blood loss; resistance to hypoxia; superoxidedismutase; catalase. 


\section{ОСОБЕННОСТИ ЭНЗИМНОГО ЗВЕНА АНТИОКСИДАНТНОЙ ЗАШИТЫ В РАННИЙ ПЕРИОД КРАНИОСКЕЛЕТНОЙ ТРАВМЫ, ОС.ОЖНЕННОЙ КРОВОПОТЕРЕЙ, У КРЫС С РАЗЛИЧНОЙ РЕЗИСТЕНТНОСТЫЮ К ГИПОКСИИ}

Цель работы: выяснить активность энзимного звена антиоксидантной защиты в динамике раннего периода краниоскелетной травмы, осложненной кровопотерей, у крыс с разной резистентностью к гипоксии.

Материалы и методы. Эксперименты выполнены на 148 нелинейных белых крысах-самцах массой 180-200 г, которые находились на стандартном рационе вивария. Предварительно у крыс определили индивидуальную устойчивость к гипоксии и выделили две группы: высоко- и низкостойких (BC, НС). У животных моделировали краниоскелетную травму и сочетали ее с острой кровопотерей. Через 1, 3 и 7 суток в печени разностойких к гипоксии животных определяли супероксиддисмутазную (СОД-) и каталазную активность.

Результаты исследований и их обсуждение. Характерной особенностью ВС животных по сравнению с НС животными контрольной группы был высокий уровень СОД- и каталазной активности печени. В ответ на краниоскелетную травму активность исследуемых ферментов в печени НС и ВС животных снижалась с максимумом через 3 суток и оставалась на таком же уровне до 7 суток. Однако в ВС животных после нанесения краниоскелетной травмы отмечали меньшую степень снижения исследуемого показателя. В условиях моделирования дополнительной кровопотери нарушения энзимного звена антиоксидантной защиты в печени были большими и росли с 1 до 7 суток. Однако в ВС животных нарушения СОД-активности во все сроки посттравматического периода было меньше. Каталазная активность в ответ на моделируемые травмы в ВС животных через 3 и 7 суток посттравматического периода была меньше как в условиях моделирования только краниоскелетной травмы, так и ее сочетание с острой кровопотерей. Полученные результаты нацеливают на необходимость учета индивидуальной устойчивости к гипоксии в разработке стратегий диагностики и коррекции травматической болезни в условиях политравмы и дифференциированного применения веществ с антиоксидантными свойствами, что требует своего дальнейшего углубленного исследования.

Ключевые слова: краниоскелетная травма; кровопотеря; устойчивость к гипоксии; супероксиддисмутазы; каталаза. 